Research.

\title{
INTERNAL CONTROL SYSTEM ANALYSIS ON ACCOUNTS RECEIVABLE IN SP CORPORATION
}

\author{
Nicholas Renaldo $^{1^{\star}}$, Sudarno ${ }^{2}$, Marice Br. Hutahuruk ${ }^{3}$ \\ Institut Bisnis danTeknologi Pelita Indonesia ${ }^{1,2}$, STIE Prakarti Mulya ${ }^{3}$ \\ nicholasrenaldo@lecturer.pelitaindonesia.ac.id ${ }^{1}$; sudarno@lecturer.pelitaindonesia.ac.id²; \\ mrctalenta@yahoo.com ${ }^{3}$ \\ * Corresponding author
}

Received: July 7, 2020; Accepted: July30,2020; Published: December 31, 2020

To cite this article: Renaldo, N., Sudarno,S., \& Hutahuruk, M.B. (2020). Internal Control System Analysis On Accounts Receivable In Sp Corporation. The Accounting Journal of BINANIAGA. 5 (2): 73-84. doi: 10.33062/ajb.v5i2.382

\begin{abstract}
This study aims to identify and determine the effectiveness of the internal control of accounts receivable at SP Corporation. The problems are there are outstanding accounts receivable and at the end of 2013-2019, that accounts receivable will be written off. The main model theory used in this research is COSO (Committee of Sponsoring Organization) to detect internal control effectiveness. This research used descriptive analysis and sign test. The conclusion based on the results of the sign test calculation showed that internal control of accounts receivable in SP Corporation is not working effectively. SP Corporation has not implemented the control environment, risk assessment, control activity, and supervision and monitoring effectively.
\end{abstract}

Keywords: Accounts Receivable, COSO, Internal Control, Sign Test

\section{INTRODUCTION}

Indonesia is a developing country and strives to be a developed country. Indonesia is doing development in various sectors in order to improve the welfare of the people and the country. This has an impact on the existing companies in Indonesia, especially the growing domestic companies.

Domestic companies in Indonesia when viewed from the type of shares consists of two types, that are open companies (go public) ie companies that sell their shares to the stock market (listing on the Indonesia Stock Exchange) and private companies ie companies that do not sell their shares to the capital market. SP Corporation (the private company name is disguised to maintain privacy) is a private company engaged in the development of Industrial Plantation Forest whose main activity is utilizing forest products in the form of natural timber and planting from the cleared land. One way for SP Corporation to grow better is to increase its sales.

In order to increase sales, management will seek to contact and attract buyers to buy their products. Such a way in the level of effectiveness will certainly increase sales from the company. Sales numbers may go up, but that does not mean the company will receive large amounts of cash, in line with the sales. Increases in company sales are not all in cash, nor can sales on credit. In making the sale, all sales in SPCorporation are done on credit so that it will result in Accounts Receivable (AR). Increased credit sales cause the company to have a receivable that is expected to be received quickly and in a short time by the company in the form of cash inflows.

Nicholas Renaldo, Sudarno and Marice Br. Hutahuruk. Internal Control System Analysis On Accounts Receivable In Sp Corporation 
This raises a problem for the management because, on the one hand, the company can increase sales; while on the other hand, the sale on credit has a greater risk because it may cause the possibility of bad debts and even the risk of bad debts if the payment is not in accordance with the agreement.

Required good internal control over the credit sales system to reduce the risk of bad debts and avoid losses in the company. In billing accounts receivable, SP Corporation always establishes and informs the buyer that the payment due is 30 days. The receivables that exceed 30 days are still billable, but there are still accounts receivable that have been more than 30 days and still can not be charged.

Table 1. Account Details of Accounts Receivable in SP Corporation (Indonesian Rupiah)

\begin{tabular}{rrrrr}
\hline Year & Total Credit Sales & More than 30 Days AR & Paid in Next Year & Outstanding AR \\
\hline 2012 & $3,126,761,900$ & 0 & 0 & 0 \\
2013 & $16,121,066,530$ & $384,819,112$ & $107,740,912$ & $277,078,200$ \\
2014 & $64,194,025,041$ & $277,078,200$ & 0 & $277,078,200$ \\
2015 & $94,410,819,557$ & $2,006,803,164$ & $1,729,724,964$ & $277,078,200$ \\
2016 & $14,217,407,963$ & $277,078,200$ & 0 & $277,078,200$ \\
2017 & 0 & $277,078,200$ & 0 & $277,078,200$ \\
2018 & 0 & $277,078,200$ & 0 & $277,078,200$ \\
2019 & 0 & $277,078,200$ & 0 & $277,078,200$ \\
\hline \multicolumn{2}{l}{ Source: SP Corporation, 2020 }
\end{tabular}

Table 1 shows that for eight years, there are three years ie 2013and 2015 where there are receivables more than 30 days. However, receivables in 2013 and 2015 are still redeemable even after 30 days. While the remaining receivables amounting to IDR $277,078,200$ still can not be billed until the end of 2019.If the company decides to write off these receivables, there will be a loss of IDR 277,078,200.

Internal control is expected to help achieve the efficiency and effectiveness of the company's operations. Business operations can be said to be effective depending on management policies. Internal control is not a guarantee that all errors or fraud can be eliminated, but a means of monitoring the company's operational activities. With good internal control, it is expected that the chance of error and fraud can be minimized and a case of error and fraud then it can be known and overcome quickly and precisely.

There are some previous studies on internal control of accounts receivable such as (Binanggal, 2016; Desantirahayu, 2017; Habibie, 2013)said that the internal control of accounts receivable has been effective in their research objects while (Afifah, Soebandhi, \& Wardhana, 2015; Ketaren, 2014; Windiyah \& Putra, 2014)said that the internal control of accounts receivable still can not run effectively in the object of their research.

With good internal control may be able to help SP Corporation in overcoming these problems so as not to cause losses too large let alone the value of large receivables can not be billed for three years.For the description of the problem and the research gap, it will be interesting to be discussed related to internal control of accounts receivable inSP Corporation. Thus, the purpose of this study is to determine the effectiveness of accounts receivable internal control inSP Corporation.

\section{Identification Of The Problem}

Based on the background mentioned above, the problem in this study is whether the implementation of internal control on SP Corporation receivables has been effective or not.

\section{Problem Limitation}

Referring to the problem identification above, this research is limited only about accounts receivable in a company.

Nicholas Renaldo, Sudarno and Marice Br. Hutahuruk. Internal Control System Analysis On Accounts Receivable In Sp Corporation 


\section{Problem Design}

Problem design of this research is to find out the implementantion of internal control on SP Corporation.

\section{Aims Of The Research}

Based on the problem formulation, the purpose of this research is to find out whether the implementation of internal control on SP Corporation receivables has been effective or not.

\section{Research Benefits}

It is hoped that the results of this research can be beneficial for the development of education both theoretically and practically. The theoretical benefit is that this research will be a scientific development in the field of accounting and auditing. This research is also useful as reading material/references for academics and also this research can subsequently be a reference for future researchers. Practical benefits are used as a repair material for companies to be able to run the business optimally.

\section{LITERATURE REVIEW}

\section{Accounting and Receivables}

Accounting can be interpreted as an information system that provides reports to users of accounting information on the results of the performance and financial condition of the company. At first, a business transaction will be identified (analyzed), recorded, and then reported through accounting reports which is a communication media accounting information. Business transactions here can be interpreted as an event or an economic event that affects changes in the company's financial position (Hery, 2014: 6).Accounting is a process that starts from transaction proven by invoice, then from transactions made journals, ledgers, worksheets, then will yield information in the form of financial statements used by certain parties (Sujarweni, 2015: 3).Based on the two terms, it can be interpreted that accounting is a process of identifying, recording, presenting and reporting starting from the collection of transaction data (invoice, receipt, and other), recording into journal, ledger, worksheet of a measurable economic event with monetary units to form a financial report that provides information in the form of financial statements that will be used parties concerned.

Accounts receivable are sums of money that clients/customers should pay for the sale of services/goods that the seller has given to the buyer(Windiyah \& Putra, 2014). In addition, (Runtu \& Elim, 2016)said receivables include all claims in the form of money against other entities, including individuals, companies, or other organizations. From both terms, it can be concluded that accounts receivable are all claims that will be repaid in the form of money from the sale of goods or services produced by the company against individual entities, companies, or other organizations.

Receivables are presented on the balance sheet in two groups, namely trade receivables and non-current accounts receivable. In general, the term receivables can be applied to all claims on money, goods, and services, but for accounting purposes, the term is generally used in a narrower scope to describe claims expected to be completed by the receipt of cash (Rusdi, 2010: 90).

Claims arising from the sale of goods or delivery of services to customers, in general, is a large part of the company's working capital. As a result of control issues and credit policies, as well as a collection of accounts receivable, it is one of the factors that need to be paid serious attention by management. The estimates relating to receivables

Nicholas Renaldo, Sudarno and Marice Br. Hutahuruk. Internal Control System Analysis On Accounts Receivable In Sp Corporation 
include, among others, income from sales, forecasts with receivables, such as write-off of accounts receivable, doubtful accounts of goods returned by the buyer to the seller because they are inconsistent with the previous agreement (Runtu \& Elim, 2016).

Receivables are classified into three parts: accounts receivable, notes receivable, and other receivables. Accounts receivable are estimated to be collectible for 30-60 days. Notes receivable credit period for more than 60 days. Other receivables, if collectible in one year, are classified as current assets and if collectible for more than one year are classified as non-current assets (Runtu \& Elim, 2016).

1. Trade Receivables are the amounts owed by the customer for goods and services that have been granted as part of normal business operations. Trade receivables are usually the most significant that the company has. Accounts receivable can be classified as follows:

a. Account receivable is the amount paid by the customer for the sale of goods and services in the ordinary course of business. The timing of payment of accounts receivable is generally between 30-60 days. This credit is made under informal agreements between sellers and buyers supported by company documents, such as sales order invoices and delivery contracts. Usually, accounts receivable are charged, although there is the possibility of interest or expense added if payment is not made within a predetermined period ie the period in which the debtor is obliged to pay off its debt.

b. Notes receivable is a written promise to pay a certain amount of money on a certain date in the future. Notes receivable may come from sales, financing, or other transactions. But note receipts mostly come from lending transactions that are given a trade receivable with a money order. Notes receivable can be longterm.

2. Non-trade receivables are all receivables arising from transactions that are indirectly related to the sale of goods or the delivery of services performed by the company, including:

a. Receivables arising from loan transactions, such as receivables to affiliated companies, employees' receivables

b. Receivables to insurance companies, for losses that are liable

c. Tax receivables paid

d. Receivables arising from orders on the sale or issuance of securities or securities such as stock receivables, bonds receivable debt bonds

e. Receivables arising and are a function of time and receivables of income such as interest receivables, rent, dividends, royalties

According to the Ikatan Akuntan Indonesia (2007: 451) based on the source of occurrence, receivables are classified into two categories: accounts receivable and other accounts receivable. Accounts receivable arise from the sale of products or services in the ordinary course of business, while accounts receivable arising outside the normal course of business are classified as other receivables.

From the above terms of credit, the method of recording accounts receivable can be divided into two methods: account receivables are recorded gross and net accounts receivable are recorded net, ie(Runtu \& Elim, 2016):

1. Accounts receivable are recorded gross

The gross method recognizes a number of the receivables of the sale without being affected by the deduction. In the event that the debtor takes a rebate, it will be recognized as a reduction in the amount of the sale rather than as a number of receivables.

2. Accounts receivable are recorded net

The net method recognizes the amount of the receivable after deducted by the sales discount if it turns out that the deductions are not utilized by the debtor, it will result in an overpayment of the number of receivables and excess as other income.

Nicholas Renaldo, Sudarno and Marice Br. Hutahuruk. Internal Control System Analysis On Accounts Receivable In Sp Corporation 
Runtu \& Elim (2016) declare unacceptable accounts receivable, such as the debtor of bankruptcy, death, and others should be eliminated and become a cost to the company. To record the write-off of accounts receivable it can be done by two methods, that is:

1. Direct method

This method is used by companies that have restaurants, hotels, hospitals, law firms, public accounting firms, and retail outlets with relatively small business scales.

2. Allowance method

Along the period during which credit sales took place, an estimate of the number of outstanding accounts receivable was made. At this point (in the sales period), because the company has not been able to know which of its customers can not pay the company will not credit (delete) the accounts receivable directly.

\section{Internal Control}

In SPAP SA section 319, internal control means a process run by the board of commissioners, management, and other personnel entities designed to provide reasonable assurance about the achievement of objectives (IAPI DSP, 2013:2).

Internal control has an understanding of the sense of narrow and broad. The internal control system in the narrow sense (internal check term), which is the mechanical procedure to check the accuracy of administrative data. While in a broad sense, the internal control system is seen as a social system that has a special meaning/insight that is different in the organization of the company. Accounting control systems and administrative control systems are included in the control system in a broad sense (Singal \& Tirayoh, 2015).

Internal control is a designed process to guarantee the achievement of objectives related to the effectiveness and efficiency of operations, the reliability of financial reporting, and compliance with applicable laws. A good understanding of internal control is best treated by managers, users of accounting systems, accounting system designers and accounting system evaluators (TMBooks, 2015:36).

The basic concept contained in the definition is:

a. Internal control is a process. This means that internal control is a way to achieve goals, not goals themselves. Internal control consists of a series of inherent and integrated actions within the unit's business infrastructure.

b. Internal control is influenced by humans. Internal control not only consists of a series of policy manuals and forms but also people at various levels within organizations, including boards of commissioners, management, and other personnel.

c. Internal control is only expected to provide reasonable assurance, rather than full confidence in the management and board of commissioners of the business unit because of the inherent weaknesses inherent in the entire internal control system and the need to consider the costs and benefits associated with the establishment of such controls.

d. Internal control is a tool for achieving objectives in matters that overlap each other ie financial reporting, conformity, and operations.

From some terms above, it can be concluded that internal control is a process to achieve the company's goals run by managements to provide reasonable assurance about the achievement of objectives and to guarantee that achievement of objectives related to the effectiveness and efficiency of operations, the reliability of financial reporting and compliance with applicable laws.

Runtu \& Elim (2016)asserted that the internal control system according to the AICPA (American Institute of Certified Public Accountants) includes the organizational structure, all the coordinated methods and provisions adopted by the company to protect the property, check the accuracy and how far the accounting data trustworthy, improve

Nicholas Renaldo, Sudarno and Marice Br. Hutahuruk. Internal Control System Analysis On Accounts Receivable In Sp Corporation 
business efficiency, and encourage compliance with established corporate policies. The definition emphasizes what it wants to achieve, not the elements that make up the system. The purpose of the internal control system by definition is:

1. Maintain the organization's wealth

Company physical property can be stolen, misused. Internal control system is established to prevent or find lost property.

2. Check the accuracy and reliability of accounting data

Management must have an accountable data that can be tested for accuracy to carry out company operations, various data used to make important decisions.

3. Encourage business efficiency

Control in a company is also intended to avoid unnecessary multiple jobs, prevent waste of all aspects of the business including the prevention of the use of efficient sources of funds.

4. Encourage compliance with management policies

Management develops procedures and regulations to achieve company goals. The internal control system provides guarantees for compliance with such procedures and regulations by the company.

Those four objectives can be classified into two types: internal accounting control and internal administrative control. Internal control of accounting, which is part of the internal control system, includes organizational structure, methods, and measures that are coordinated primarily to safeguard the organization's wealth and check the accuracy and reliability of accounting data. Administrative internal control including organizational structures, methods, and measures that are coordinated primarily to promote efficiency and compliance with management policies.

The internal control system consists of policies and procedures designed to provide reasonable assurance for management, that the company has achieved its goals and objectives (Hery,2011:87). The COSO (Committee of Sponsoring Organization) model is an internal control model used by auditors as a basis for evaluating and developing internal controls(Desantirahayu, 2017).

coso considers internal control a comprehensive set of actions within the organization. COSO also makes it clear that internal controls are in the process of basic management, ie planning, implementation, and monitoring. Control is not something added to the management process but is an integral part of the process(Desantirahayu, 2017).

COSO states there are three purposes of internal control ie(Habibie, 2013):

1. Effectiveness and efficiency of operations

2. Financial reporting reliability

3. Compliance with existing rules and regulations

Internal control has several benefits, but internal controls still have a number of weaknesses as follows (Jusup, 2011:13):

1. Internal controls are susceptible to human weaknesses, such as physical and mental fatigue of employees and saturation that can reduce the work of work.

2. Collusion or cooperation among dishonest employees to commit offenses/crimes is often unavoidable by the system.

3. Internal controls are generally applied to daily routine transactions, whereas unusual or non-supervised transactions occurring at the end of the year.

4. Cost factors are often a constraint, so not all control objectives can be achieved.

5. Control applied by the company is often not synchronized with the developments that occur within the company.

According to COSO (Sanyoto, 2007: 267), there are five internal control components. Those five components of internal control are:

1. Control Environment

Nicholas Renaldo, Sudarno and Marice Br. Hutahuruk. Internal Control System Analysis On Accounts Receivable In Sp Corporation 
These components include management attitudes at all levels of general operations and the concept of control in particular. The control environment provides a tone to an organization, affecting the control awareness of its members. The control environment is the basis for other internal control components, providing discipline and structure. Factors that shape the control environment include integrity and ethical values, commitment to competence, the board of commissioners or audit committees, management philosophy and operating style, organizational structure, empowerment and responsibility, and human resource policies and practices.

2. Risk Assessment

Risk assessment for financial reporting purposes is the identification, analysis, and management of entity risks related to the preparation of financial statements, in accordance with generally accepted accounting principles. COSO adds consideration to goals in all areas of operations to ensure that all parts of the organization work in harmony. Factors influencing the determination of risks in internal control are changes in the operating environment, changes in the structure or composition of new personnel, the development of information systems, organizational growth, and the use of new technologies, the development of new operations and operating areas and the issuance of new accounting standards.

3. Control Activities

Control procedures are established to standardize the work process so as to ensure the achievement of corporate objectives and prevent or detect the occurrence of irregularities and errors. Generally, control activities that may be relevant to the audit may be classified as policies and procedures relating to the review of performance, information processing, physical control and asset control, adequate documentation and records, adequate segregation of duties, proper authorization of transactions and activities and the presence of new policies to prevent risks that are detrimental to the company.

4. Information and Communication

The accounting system contains procedures that must be adhered to by company personnel and able to provide accurate information to parties in need, especially for management, and can establish communication between the existing parts so that the uniform implementation. The information system relevant to the purpose of financial reporting, which includes the accounting system, consists of methods and records built to record, manage, summarize and report on entity transactions (including events and circumstances) and to hold accountability for the related assets, liabilities, and equities. The quality of information generated by the system affects the ability of management to make decisions that should be in managing and controlling the activities of entities to prepare reliable financial statements.

Communication involves providing an understanding of individual roles and responsibilities with respect to internal control over financial reporting. Communication includes the breadth of personnel understanding of how their activities in financial reporting information systems relate to the work of others and how to report deviations to the level that should be in the ethnic.

Factors affecting information and communication in internal control are the identification of all transactions, providing information in a timely manner, recording the various transactions into the correct transaction code, and communication.

5. Supervision and Monitoring

Monitoring is a process of quality performance assessment of the internal control structure that is applied to achieve the objectives and reviewed if feasibility is no longer appropriate to the existing situation. An optimal monitoring system can avoid the incidence of bad debts. The effective internal control structure has the objective of efficiency, effectiveness, and internal control of the company's assets and other supporting facilities. Factors that influence the implementation of good supervision and

Nicholas Renaldo, Sudarno and Marice Br. Hutahuruk. Internal Control System Analysis On Accounts Receivable In Sp Corporation 
monitoring in internal control are periodic examination, sudden inspection, and rotation of position.

There are several previous studies on the internal control of accounts receivable.The effective results were found by(Binanggal, 2016; Desantirahayu, 2017; Habibie, 2013; Lafiah \& Abriandi, 2014; Runtu \& Elim, 2016; Saraswati \& Yadnyana, 2014; Singal \& Tirayoh, 2015; Wensen, Kawet, \& Saerang, 2016)and the opposite results were found by (Afifah et al., 2015; Ketaren, 2014; Windiyah \& Putra, 2014).

\section{RESEARCH METHODOLOGY}

This research has applied qualitative approach. Variables of this research are the internal control of account receivables on SP Corporation.

\section{Place and Time of the Research}

This research was conducted in 2020 and the object of research is SP Corporation located at Pekanbaru, Riau.

\section{Types and Data Sources}

The data type is primary data obtained directly from SP Corporation's staff and secondary data obtained from the second party and already processed by the first party and also observation data obtained through a questionnaire, interview, observation, and documentation.

\section{Operational Variables}

Accounts receivable are all claims that will be repaid in the form of money from the sale of goods or services produced by the company against individual entities, companies, or other organizations.

Internal control is a process to achieve the company's goals run by managements to provide reasonable assurance about the achievement of objectives and to guarantee that achievement of objectives related to the effectiveness and efficiency of operations, the reliability of financial reporting and compliance with applicable laws.

\section{Data Analysis Techniques}

1. Descriptive analysis, the method of analysis by first collecting existing data and then doing the clarification, analyzed subsequently interpreted so as to provide a clear picture of the existence of the studied (SumarnidanSalamah, 2005:101).

2. The sign test is the test intended to see the difference and not the magnitude of difference and based on the procedure on the positive (+) and negative (-) sign of the difference between ordinal data pair (Atmaja, 2009:114). For the sample size $\leq 30$ will be used binomial test with the decision if the cumulative probability $\leq 0.95$ then $\mathrm{H}_{0}$ accepted. As for the number of samples $>30$ will be used large sample sign test with the decision making terms ifZCount $\leq 1.645$ then $\mathrm{H}_{0}$ accepted. The formulas used in this research are:

$$
\begin{aligned}
\mathrm{P}(\mathrm{r}) & =\frac{n !}{r !(n-r) !} \times p^{r} \times q^{n-r} \\
Z_{\text {Statistic }} & =\frac{2 r-n}{\sqrt{n}}- \\
\mathrm{P}(\mathrm{r}) & : \text { chance occurrence }(r) \text { expected for binomial test } \\
Z_{\text {Statistic }} & : \text { value of } \mathrm{z} \text { statistic for big sample test }
\end{aligned}
$$

Nicholas Renaldo, Sudarno and Marice Br. Hutahuruk. Internal Control System Analysis On Accounts Receivable In Sp Corporation 
n

$r$

$p$

q number of experiments / samples

number of success(es) / yes answer(s)

chance of success / "yes" answer elected

chance of failure / "no" answer elected

\section{Statistics Hypotheses}

1. The control environment on credit sales and billing accounts receivable activity in SP Corporation has been implemented effectively.

2. The risk assessment on credit sales and billing accounts receivable activity in SP Corporation has been implemented effectively.

3. The control activity on credit sales and billing accounts receivable activity in SP Corporation has been implemented effectively.

4. The information and communication on credit sales and billing accounts receivable activity in SP Corporation has been implemented effectively.

5. The supervision and monitoring on credit sales and billing accounts receivable activity in SP Corporation has been implemented effectively.

6. The internal control on accounts receivable in SP Corporation has been implemented effectively.

\section{RESULT AND DISCUSSION}

\section{Credit Sales Activity Sign Test}

The summary table about the credit sales activity sign test can be seen in table 2 .

Table 2. Result of the Credit Sales Internal Control in SP Corporation

\begin{tabular}{|c|c|c|c|c|c|c|}
\hline No & Dimension & Sample Test & \multicolumn{3}{|c|}{ Result } & Explanation \\
\hline 1 & Control Environment & Binomial Test & 0.2617 & 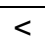 & 0.95 & Not Effective \\
\hline 2 & Risk Assessment & Binomial Test & 0.8204 & $<$ & 0.95 & Not Effective \\
\hline 3 & Activity Control & Binomial Test & 0.6855 & $<$ & 0.95 & Not Effective \\
\hline 4 & Information and Communication & Binomial Test & 0.9980 & $>$ & 0.95 & Effective \\
\hline 5 & Supervision and Monitoring & Binomial Test & 0.3633 & $<$ & 0.95 & Not Effective \\
\hline 6 & Credit Sales Internal Control & Big Sample Test & 0.5774 & $<$ & 1.645 & Not Effective \\
\hline
\end{tabular}

Based on table 2, the only effective result just information and communication dimension, and the other dimensions have not implemented effectively. The conclusion is credit sales internal control overall has not implemented effectively in SP Corporation.

\section{Billing Accounts Receivable Activity Sign Test}

Table 3. Result of the Billing Accounts Receivable Internal Control in SP Corporation

\begin{tabular}{|c|c|c|c|c|c|c|}
\hline No & Dimension & Sample Test & \multicolumn{3}{|c|}{ Result } & Explanation \\
\hline 1 & Control Environment & Binomial Test & 0.2617 & $<$ & 0.95 & Not Effective \\
\hline 2 & Risk Assessment & Binomial Test & 0.8204 & $<$ & 0.95 & Not Effective \\
\hline 3 & Activity Control & Binomial Test & 0.6855 & $<$ & 0.95 & Not Effective \\
\hline 4 & Information and Communication & Binomial Test & 0.9893 & $>$ & 0.95 & Effective \\
\hline 5 & Supervision and Monitoring & Binomial Test & 0.3633 & $<$ & 0.95 & Not Effective \\
\hline 6 & Billing Accounts Receivable Internal Control & Big Sample Test & 0.4588 & $<$ & 1.645 & Not Effective \\
\hline
\end{tabular}

Based on table 3 , the only effective result just information and communication dimension, and the other dimensions have not effectively done. The conclusion is billing accounts receivable internal control overall have not implemented effectively in SP Corporation.

\section{Accounts Receivable Internal Control Sign Test}

Table 4. Result of the Accounts Receivable Internal Control in SP Corporation

Nicholas Renaldo, Sudarno and Marice Br. Hutahuruk. Internal Control System Analysis On Accounts Receivable In Sp Corporation 


\begin{tabular}{clcccc}
\hline No & \multicolumn{1}{c}{ Dimension } & Sample Test & Result & Explanation \\
\hline 1 & Control Environment & Big Sample Test & -1.2060 & $<1.645$ & Not Effective \\
2 & Risk Assessment & Big Sample Test & $0.9733<$ & $<1.645$ & Not Effective \\
3 & Activity Control & Big Sample Test & 0.3430 & $<1.645$ & Not Effective \\
4 & Information and Communication & Binomial Test & 0.9996 & $>0.95$ & Effective \\
5 & Supervision and Monitoring & Binomial Test & 0.2272 & $<0.95$ & Not Effective \\
6 & Account Receivable Internal Control & Big Sample Test & 0.7324 & $<1.645$ & Not Effective \\
\hline \multicolumn{2}{l}{ Source: Processed data, 2020 }
\end{tabular}

Based on table 4, the only effective result just information and communication dimension, and the other dimensions have not effectively done. The conclusion is accounts receivable internal control overall has not implemented effectively.

\section{Description}

Control Environment. SP Corporation in credit sales and billing accounts receivable is not fully implemented the integrity and ethic in the company. Overall, it has a commitment to competence and already gives its employee position and responsibility. But, some employees are not aware of the importance of internal control in the company. Boards of commissioners have not fully participated in the company's activities but already active with the manager to prevent the fraud. For philosophy and operational management style, organization structure and policy and human resources practice are not fully implemented in the company. Because of control environment is not fully implemented in the company, this will affect the company's activity especially credit sales and billing accounts receivable activity.

Risk Assessment. SP Corporation in credit sales and billing accounts receivable activity already covered its employees in insurance. Because the company does not have the organizational structure, the company's performance will be affected. The company does not follow the information system development in technology. All the ideas always come from the commissaries council and operational activity always supervised by the manager. Activity development and new accountancy standard already goodly implemented. Because of this risk assessment is not fully implemented in the company, this will affect the company's activity especially credit sales and billing accounts receivable activity.

Control Activity. SP Corporation in credit sales and billing accounts receivable activity always review the employee's work but does not give value and appreciation for a good employee. All of the informations are processed goodly between management, manager, and employee. The physic control and the supervision of assets are already done by management. There are some policies about how to minimize the risk but, on the other hand, some employees have double jobs, and management does not give the right authorization on transaction and activity that might minimize the risk. Because of this control activity is not fully implemented in the company, this will affect the company's activity especially credit sales and billing accounts receivable activity.

Information and Communication. SP Corporation in credit sales and billing accounts receivable activity overall already identify all the transaction, employees give information in the correct time and accounting department entry the transaction in the correct journal also the communication between management and employee already running smoothly but, they never exchange their opinion about company's activity. Because of this information and communication almost fully implemented in the company, information and communication on credit sales and billing accounts receivable activity has been done effectively in SP Corporation.

Supervision and Monitoring. SP Corporation in credit sales and billing accounts receivable activity already does a periodical check on policy and procedure in the company but does not have the internal check or supervision department. The company does a check periodically but never did it suddenly that will make employee tend to be 
lazy to work on a regular day. Also, the company never does an employee rotation and promotion. Because of this supervision and monitoring are not fully implemented in the company, this will affect the company's activity especially credit sales and billing accounts receivable activity.

\section{CONCLUSIONS AND RECOMMENDATIONS}

Based on the research result and from the findings conducted, the conclusions that can be taken are:

1. Internal control on credit sales activity has not implemented effectively in SP Corporation.

2. Internal control on billing accounts receivable activity has not implemented effectively in SP Corporation.

3. Control environment, risk assessment, control activity, and supervision and monitoring on accounts receivable have not implemented effectively in SP Corporation and only information and communication dimensionsthat already implemented effectively in SP Corporation.

4. Overall, the accounts receivable internal control in SP Corporation has not implemented effectively.

Based on the research result and from the findings conducted, the recommendations that can be given are:

1. SP Corporation needs to improve the control environment first because this dimension has the lowest signification level by applying practiced the philosophy and operational management style, integrity value and ethic and policy, and human resource practice to the company's employees. The company also needs to restructure the organization structure to ensure the internal control has been work properly.

2. After improving the control environment, SP Corporation needs to improve supervision and monitoring by does a sudden inspection and gives a reward for the excel employees.

3. SP Corporation needs to improve activity control by giving a separate job for employees, gives authorization for some action to the employee to minimize the risk, and also gives a reward for the excel employees.

4. The implementation of risk assessment is almost approached effective but SP Corporation still needs to improve that by using some new technologies and develops a good information system.

5. SP Corporation still needs to keep the stability of information and communication to keep this dimension running effectively.

6. The next research is expected to develop this research and use another research method so that it can be compared to the results of this research and also find the alternative indicator to prove the effectiveness of internal control.

\section{REFERENCE}

Afifah, N. N., Soebandhi, S., \& Wardhana, R. (2015). Analisis Sistem Pengendalian Internal atas Piutang pada PT GIS. E-Jurnal Spirit Pro Patria, 1(1), 54-68.

Atmaja, Lukas Setia. (2009). Statistika untuk Bisnis dan Ekonomi. CV ANDI OFFSET.

Binanggal, C. V. (2016). The Internal Control Analysis of Account Receivables at PT Tunas Dwipa Matra Branch Manado. Jurnal EMBA, 4(3), 147-155.

Desantirahayu, E. (2017). Analisis Pengendalian Intern Model "COSO" terhadap Piutang

Nicholas Renaldo, Sudarno and Marice Br. Hutahuruk. Internal Control System Analysis On Accounts Receivable In Sp Corporation 
The Accounting Journal of BINANIAGA Vol. 05, No. 02, December 2020

p-ISSN: 2527-4309, e-ISSN: 2580-1481

$5^{\text {th }}$ Accreditation Rating: January 14, 2019 - January 13, 2024

Usaha. AKADEMIKA, 15(1), 14-21.

Dewan Standar Publik Ikatan Akuntansi Publik Indonesia. (2013). Standar Profesional Akuntan Publik. Jakarta: Salemba Empat.

Habibie, N. (2013). Analisis Pengendalian Intern Piutang Usaha pada PT Adira Finance Cabang Manado. Jurnal EMBA, 1(3), 494-502.

Hery. (2011). Akuntansi: Aktiva, Utang dan Modal. Gava Media.

. (2014). Akuntansi Dasar 1 dan 2. PT Gramedia Widiasarana Indonesia.

Ikatan Akuntan Indonesia. (2007). Standar Akuntansi Keuangan. Salemba Empat.

Jusup, A.H. (2011). Dasar-dasar Akuntansi Jilid 2 Edisi ke 7. Sekolah Tinggi IImu Ekonomi YKPN.

Ketaren, A. (2014). Analisis Sistem Pengendalian Internal Piutang pada Koperasi Serba Usaha (KSU) Surya Pelita. Jurnal Ilmiah Accounting Changes, 2(2), 40-47.

Lafiah, J., \& Abriandi. (2014). Analisis Efektivitas Sistem Pengendalian Internal atas Piutang Usaha dan Pengaruhnya terhadap Kolektibilitas Piutang Usaha. Kalbisocio, 1(1), 42-53.

Runtu, R. D., \& Elim, I. (2016). Analysis of Internal Control Trade Receivables in PT Bussan Auto Finance (BAF) Manado. Jurnal EMBA, 4(1), 536-545.

Rusdi, A. (2010). Akuntansi Pengantar. YKPN.

Sanyoto, G. (2007). Audit Sistem Informasi. Erlangga.

Saraswati, L., \& Yadnyana, I. K. (2014). Pengaruh Struktur Pengendalian Intern terhadap Kelancaran Pengembalian Kredit pada Koperasi Simpan Pinjam di Kota Denpasar. E-Jurnal Akuntansi Universitas Udayana, 7(1), 122-134.

Singal, C. R., \& Tirayoh, Vi. Z. (2015). Analisis Pengendalian Internal Piutang Usaha pada Developer Grand Kawanua International City. Jurnal EMBA, 3(1), 286-296.

Sujarweni, (2015). Sistem Akuntansi. Pustaka Baru Press.

Sumarni, Murli dan Wahyuni Salamah. (2005). Metodologi Penelitian Bisnis. CV Andi.

TMBooks. (2015). Sistem Informasi Akuntansi - Konsep dan Penerapan. CV Andi.

Wensen, A. C., Kawet, L., \& Saerang, I. (2016). The Analysis of Internal Control of Accounts Receivables on PT Buana Finance Tbk Manado. Jurnal EMBA, 4(3), 201-208.

Windiyah, I. N., \& Putra, I. S. (2014). Analisis Pengendalian Internal pada Piutang Usaha di UD Satwa Unggul. Riset Mahasiswa Ekonomi, 1(1), 70-87.

Nicholas Renaldo, Sudarno and Marice Br. Hutahuruk. Internal Control System Analysis On Accounts Receivable In Sp Corporation 